\title{
Pembaruhan Hukum Islam Dalam Kompilasi Hukum Islam Sebagai Upaya Positivisasi Hukum
}

\author{
Abduh Sulaeman \\ Alumni Program Studi Doktor Ilmu Hukum \\ Pascasarjana Universitas Islam Bandung \\ e-mail: abduh.sulaeman@yahoo.com
}

\begin{abstract}
Abstrak- Kompilasi Hukum Islam (KHI) adalah salah satu contoh reformasi hukum Islam di Indonesia, khususnya dalam upaya kepositifan hukum. Penelitian ini berfokus pada keberadaan reformasi hukum Islam di Indonesia sesuai dengan rumusan Kompilasi Hukum Islam (KHI). Penelitian ini menggunakan penelitian hukum normatif deskriptif melalui studi literatur bahan hukum primer dan sekunder, yang berkaitan dengan substansi penelitian. Studi ini menyimpulkan bahwa keberadaan reformasi hukum Islam dapat dilihat baik dari sudut pandang kelembagaan dan sudut pandang substansial. Secara kelembagaan, KHI telah dibentuk melalui ijtihad jama'i oleh beberapa perwakilan lembaga negara dan dibentuk oleh lembaga negara (Mahkamah Agung Indonesia dan Kementerian Agama Indonesia). Secara substansial, reformasi dibatasi pada hukum Islam yang diberikan oleh argumen żanny, khususnya untuk qaḍa'I ketentuan hukum Islam dan penggunaan argumen umum sebagai bentuk dukungan postulat syar'i.
\end{abstract}

Kata kunci: Kompilasi Hukum Islam, Reformasi hukum Islam, kepositifan hukum.

\begin{abstract}
Compilation of Islamic Law (KHI) is one example of Islamic law reform in Indonesia, specifically in the efforts of legal positivity. This study focuses on the existence of Islamic law reform in Indonesia in accordance with the formulation of Compilation of Islamic Law (KHI). This study uses a descriptive normative legal research through a literature study of primary and secondary legal materials, which are related to the substance of the study. This study concluded that the existence of Islamic law reform can be seen either from institutional point of view and substantial point of view. Institutionally, KHI have been established through ijtihad jama'i by several representations of state institutions and formed by state institutions (the Supreme Court of Indonesia and the Indonesian Ministry of Religion). Substantially, the reform was limited on the Islamic law provided by the arguments of zanny, particularly for qada'I Islamic law provisions and the use of general arguments as a form of syar'i postulate support.
\end{abstract}

Keywords: The Compilation of Islamic Law, Islamic law reform, legal positivity.

\section{A. PENDAHULUAN}

Pembaruan hukum Islam
dapat diartikan sebagai suatu
upaya dan perbuatan melalui
proses tertentu (dengan penuh

kesungguhan) yang dilakukan oleh mereka yang mempunyai kompetensi dan otoritas dalam pembangunan hukum Islam (mujtahid) dengan cara-cara 
tertentu berdasarkan kaidah-kaidah istinbath atau ijtihad yang dibenarkan, dalam rangka menjadikan hukum Islam lebih segar dan tampak tidak ketinggalan zaman atau menjadikan hukum Islam yang senantiasa shahīh $f \mathfrak{i}$ kulli zamān wa makān.

\section{Berkaitan dengan}

keberadaan hukum Islam sebagai pedoman hidup yang harus diterapkan dalam pergaulan hidup manusia (masyarakat), maka selain faktor keharusan adanya pembaruan hukum Islam, juga diperlukan adanya faktor keterlibatan negara dalam keberlangsungan penerapan hukum Islam dalam bentuk positivisasi hukum.

Mempertanyakan upaya pelaksanaan pembaruan hukum Islam dalam upaya positivisasi hukum menjadi relevan karena meskipun secara filosofis dan konsepsional dimungkinkan adanya pembaruan hukum Islam, namun karena hukum Islam adalah hukum agama yang selalu dipahami sebagai hukum Tuhan yang teraktualisasi dalam bentuk wahyu yang diturunkan oleh Allah swt berupa Al-Qur'an dan Sunnah, membawa konsekuensi adanya pemahaman bahwa metode penemuan dan pembentukan hukum Islam selalu dengan pendekatan deduktif atau sumbersumber tekstual (nash) dan terlalu sedikit digunakan pendekatan induktif yang berangkat dari partikular-partikular yang bersumber dari realitas hidup masyarakat.

Spesifikasi hukum Islam yang bersumber dari Allah swt yang terkodifikasi dalam AlQur'an dan sunnah, memberi kesan adanya pengabaian dan pembiaran terhadap persepsi dan prilaku masyarakat. Hukum di dalam ajaran Islam dipahami sebagai institusi yang tidak berakar ataupun dicangkokkan pada sosiologis. Hukum Islam adalah hukum yang dipahami sebagai sarana untuk mengabdi kepada Tuhan dan bukan kepada masyarakat. Hukum dalam Islam secara teoritis bukanlah hukum yang diciptakan oleh manusia melainkan oleh Tuhan untuk 
seluruh orang Islam. Bustanul Arifin menyatakan bahwa sesuai dengan tujuan hukum Islam (taabbudi), maka metode penemuan hukumnya adalah deduktif dan kasuistik. Setiap peristiwa hukum haruslah diatur menurut aturan-aturan pokok yang terdapat dalam sumber utama Islam, Al-Qur'an dan Sunnah Nabi. Sebaliknya hukum sipil memakai metode induktif, yakni dengan mengamati perbuatanperbuatan dan sikap anggota masyarakat disimpulkan kadar kesadaran hukum masyarakat itu (Busthanul Arifin, 1996:45). Pembentukan hukum positif harus didasarkan atas pengakuan masyarakat karena harus mencerminkan rasa keadilan dan memenuhi kebutuhan masyarakat dan dalam rangka itu apresiasi (penghargaan) terhadap hukum yang hidup di dalam masyarakat (living law) harus menjadi acuan utama bagi organ yang berwenang membentuk hukum positif.

Salah satu bentuk pembaruan hukum Islam melalui positivisasi hukum Islam yang dipandang lebih khas dan intens adalah ketika adanya perumusan Kompilasi Hukum Islam yang berawal dengan keluarnya Surat Keputusan Bersama Ketua Mahkamah Agung RI dan Menteri Agama RI Nomor 07/KMA/1985 dan Nomor 25 Tahun 1985 tanggal 21 Maret 1985 tentang Penunjukan Pelaksana Proyek Pembangunan Hukum Islam melalui Yurisprudensi, sampai kepada keluarnya Inpres Nomor 1 Tahun 1991 tanggal 10 Juni 1991 dan Keputusan Menteri Agama Nomor 154 Tahun 1991 tanggal 22 Juli 1991.

$$
\text { Pelaksana Proyek }
$$

Pembangunan Hukum Islam melalui Yurisprudensi merupakan institusi yang melahirkan Kompilasi Hukum Islam setelah melalui berbagai proses dan pelibatan berbagai kelompok masyarakat, sedangkan Instruksi Presiden Nomor 1 tahun 1991 yang ditujukan kepada Menteri Agama merupakan dasar hukum pemberlakuan Kompilasi Hukum Islam. Adapun Keputusan Menteri Agama Nomor 154 Tahun 1991 
tanggal 22 Juli 1991, merupakan tindak lanjut pelaksanaan Instruksi Presiden tentang pemberlakuan Kompilasi Hukum Islam.

Kompilasi Hukum Islam (KHI) yang berisikan rangkuman berbagai pendapat hukum dari kitab-kitab fikih untuk dijadikan sebagai pertimbangan bagi hakim agama dalam mengambil keputusan dan disusun secara sistematis menyerupai kitab perundang-undangan (terdiri dari bab-bab dan pasal-pasal), dapat disebut sebagai salah satu bagian dari upaya pembaruan hukum Islam di Indonesia. Kompilasi Hukum Islam disebut sebagai bagian dari upaya pembaruan hukum Islam, karena materi hukum Islam yang ditulis dalam kitab-kitab fikih dan banyak diikuti oleh masyarakat Indonesia, telah mengalami pembaruan dalam Kompilasi Hukum Islam, bahkan diberbagai bidang beberapa gagasan baru dalam KHI tersebut tidak pernah tercetus secara resmi dalam kitab-kitab fikih sebelumnya, seperti ahli waris pengganti, pelembagaan harta bersama dalam perkawinan, pelarangan perkawinan beda agama, kewarisan anak angkat melalui wasiat wajibah, dan sebagainya.

Dengan demikian diperlukan adanya penelusuran tentang keberadaan pembaruan hukum Islam dalam perumusan Kompilasi Hukum Islam sebagai upaya positivisasi hukum di Indonesia.

\section{B. HASIL DAN PEMBAHASAN}

1. Materi Pembaruan Hukum Islam dalam Kompilasi

\section{Hukum Islam}

Seperti telah dijelaskan pada pembahasan sebelumnya bahwa Kompilasi Hukum Islam sebagai upaya positivisasi hukum Islam di Indonesia merupakan fikih Indonesia. Dikatakan sebagai fikih Indonesia karena rumusan $\mathrm{KHI}$ disamping didasarkan pada dalildalil hukum Islam, juga memperhatikan keadaan yang berlaku secara global serta mempertimbangkan tatanan hukum yang dipraktekkan oleh masyarakat yang dipandang memiliki titik temu dengan tatanan 
hukum Islam, sehingga untuk beberapa bagian tertentu rumusan Kompilasi Hukum Islam mengalami pembaruan dalam arti terjadi perbedaan antara ketetentuan yang dirumuskan dalam Kompilasi Hukum Islam dengan hukum yang dirumuskan pada kitab-kitab fikih yang disusun sebelumnya.

Di antara materi hukum Islam yang mengalami pembaruan dalam Kompilasi Hukum Islam akan dikemukakan sebagai berikut:

\section{a. Keharusan}

adanya

Pencatatan ketika

\section{Melangsungkan Pernikahan}

Ketentuan mengenai adanya pencatatan ketika melangsungkan pernikahan, tidak pernah disebut dalam berbagai kitab fikih, namun dalam Kompilasi Hukum Islam telah ditetapkan adanya sebuah keharusan untuk melakukan pencatatan ketika perkawinan dilangsungkan.

Ketentuan ini disebut dalam pasal 5 ayat (1) KHI yang menyatakan "Agar terjamin ketertiban perkawinan bagi masyarakat Islam setiap perkawinan harus dicatat", (2) Pencatatan perkawinan tersebut pada ayat (1) dilakukan oleh Pegawai Pencatat Nikah sebagai mana yang diatur dalam Undangundang No. 22 Tahun 1946 Jo. Undang-undang No. 32 tahun 1954”. Aturan seperti ini, telah dipertegas sebelumnya pada pasal 2 ayat (2) Undang-Undang Nomor 1 Tahun 1974 tentang Perkawinan. Sebagai tindak lanjut dari pelaksanaan ketentuan yang disebutkan di atas, maka dalam Pasal 6 KHI dinyatakan: “(1) untuk memenuhi ketentuan dalam Pasal 5, setiap perkawinan harus dilangsungkan di hadapan dan di bawah pengawasan Pegawai Pencatat Nikah, (2) Perkawinan yang dilakukan di luar pengawasan Pegawai Pencatat Nikah tidak mempunyai kekuatan hukum”.

Ketentuan pencatatan pernikahan ini tidak pernah ditulis dalam kitab-kitab fikih sebelumnya, kecuali pada berbagai ketentuan yang dibuat oleh instrumen negara melalui legislasi hukum seperti di Yordania dalam Qanūn huqūq al Aliah atau Law of 
Family Rights Nomor 92 tahun 1951 terakhir diamandemen dengan UU Nomor 61 tahun 1976 dinyatakan pada pasal 17 ayat $(\mathrm{c} / 3)$ perkawinan yang dilakukan tanpa dicatatkan dalam catatan resmi mengakibatkan orang yang melakukan akad nikah, mempelai dan saksi dapat dijatuhi hukuman sesuai dengan hukuman yang berlaku dalam hukum Yordania (Khoiruddin

Nasution, 2002:155).

b. Keharusan adanya Izin dari Pengadilan bagi seorang lelaki yang akan melangsungkan pernikahan secara poligami

Poligami dalam Islam merupakan praktik yang diperbolehkan (mubah), tidak dilarang namun tidak dianjurkan. Islam memperbolehkan seorang pria beristeri hingga empat orang istri dengan syarat sang suami harus dapat berbuat adil terhadap seluruh istrinya. Al-Quran Surat an-Nisa ayat 3 menyebutkan:

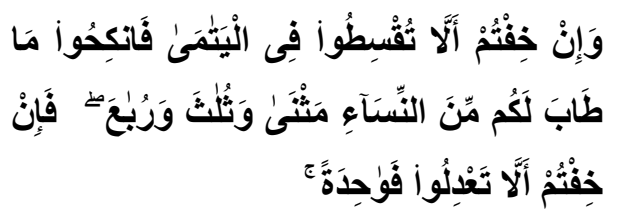

Artinya: "Dan jika kamu takut tidak akan dapat berlaku adil terhadap (hak-hak) perempuan yatim (bilamana kamu menikahinya), maka nikahilah wanita-wanita (lain) yang kamu senangi: dua, tiga, atau empat. Kemudian jika kamu takut tidak akan dapat berlaku adil, maka (nikahilah) seorang saja, ...” (Departemen Agama Republik Indonesia, 2005:99-100).

Dalam kitab fikih, tidak ditemukan adanya persyaratan yang ketat bagi seorang suami yang akan melangsungkan perkawinan poligami, sementara dalam Kompilasi Hukum Islam, setiap orang yang akan melakukan perkawinan poligami harus terlebih dahulu memperoleh izin dari pengadilan. Pengaturannya terdapat pada pasal 56 Kompilasi Hukum Islam yang menyebutkan (1) suami yang hendak beristeri lebih dari satu orang harus mendapat izin dari Pengadilan Agama (2) Pengajuan permohonan izin dimaksud pada ayat (1) dilakukan menurut tata cara sebagaimana diatur dalam Bab 
VIII Peraturan Pemerintah Nomor 9 tahun 1975. (3) Perkawinan yang dilakukan dengan isteri kedua, ketiga atau keempat tanpa izin dari Pengadilan Agama, tidak mempunyai kekuatan hukum. Kemudian pasal 57 Kompilasi Hukum Islam menyebutkan Pengadilan Agama hanya memberikan izin kepada seorang suami yag akan beristeri lebih dari seorang apabila: a. Isteri tidak dapat menjalankan kewajiban sebagai isteri, b. Isteri mendapat cacat badan atau penyakit yang tidak dapat disembuhkan, c. Isteri tidak dapat melahirkan keturunan.

\section{c. Syarat usia pasangan calon suami isteri yang akan melangsungkan perkawinan.}

Dalam kitab-kitab fikih yang ditulis sebelumnya batasan umur mengenai usia perkawinan ini hanya disebut telah memasuki usia balig, sementara di kalangan Imam Madzhab terjadi perbedaan dalam menetapkan usia balig seseorang. Syafi'i, Hambali dan Maliki tidak membedakan usia balig antara anak laki-laki dan perempuan, meskipun terjadi perbedaan dalam penetapan batas umurnya. Syafi'i dan Hambali menetapkan usia balig untuk anak laki-laki dan perempuan adalah lima belas tahun, sedang Maliki menetapkan tujuh belas tahun. Bebeda dengan Imam Abu Hanifah yang membedakan batas usia balig antara laki-laki dan perempuan, yaitu usia balig bagi anak laki-laki adalah delapan belas tahun, sedangkan anak perempuan tujuh belas tahun (Muhammad Jawad Mughniyah, 2007:317).

Ketentuan batas usia bagi calon mempelai yang akan melangsungkan perkawinan sebagaimana disebutkan dalam berbagai kitab fikih berbeda dengan rumusan Kompilasi Hukum Islam yang memberikan ketegasan mengenai usia bagi calon mempelai untuk melangsungkan perkawinan yaitu untuk calon suami sekurangkurangnya 19 tahun dan untuk perempuan sekurang-kurangnya 16 tahun. Hal ini dapat dilihat pada pasal 15 ayat (1) KHI, "Untuk kemaslahatan keluarga dan rumah 
tangga, perkawinan hanya boleh dilakukan calon mempelai yang telah mencapai umur yang ditetapkan dalam pasal 7 Undangundang Nomor 1 Tahun 1974 yakni calon suami sekurangkurangnya berumur 19 tahun dan calon isteri sekurang-kurangnya berumur 16 tahun

\section{d. Ketentuan Perkawinan Beda}

\section{Agama}

Di dalam kiktab fikih pada umumnya, perkawinan antar pemeluk agama masih dimungkinkan, yaitu antara seorang laki-laki muslim dengan wanita kitābiyah, yang menurut beberapa pendapat adalah mereka yang bergama Yahudi dan Nasrani.

Kebolehan laki-laki muslim mengawini wanita kitābiyah karena wanita kitābiyah berpedoman kepada kitab yang aslinya berasal dari wahyu Allah. Pemahaman ini didasarakan pada Al-Quran Surah al Maidah ayat 5:

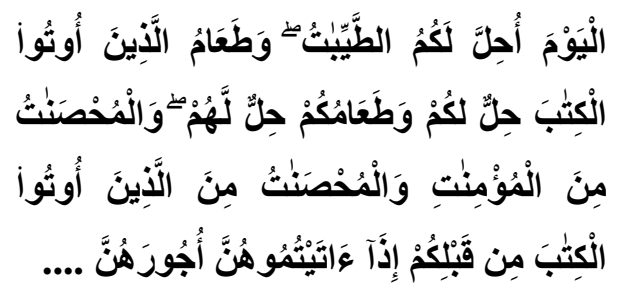

Artinya: "Pada hari ini dihalalkan bagimu yang baik-baik, makanan (sembelihan) orang-orang yang diberi al Kitab itu halal bagimu, dan makanan kamu halal (pula) bagi mereka. (dan dihalakan mengawini) wanita-wanita yang menjaga kehormatan diantara wanita-wanita yang beriman dan wanita-wanita yang menjaga kehormatan diantara orang-orang yang diberi al Kitab sebelum kamu, bila kamu telah membayar mas kawin mereka dengan maksud menikahinya, ..." (Departemen Agama Republik Indonesia, 2005:143).

Ketentuan

mengenai perkawinan beda agama yang termuat dalam berbagai kitab fikih tersebut telah mengalami pembaruan dalam proses pembaruan hukum Islam melalui Kompilasi Hukum Islam. Dalam Kompilasi Hukum Islam (termasuk juga dalam Undang-undang Nomor 1 tahun 1974 tentang Perkawinan) telah ditetapkan bahwa keabsahan suatu perkawinan apabila dilaksanakan menurut hukum agama dan 
kepercayaannya masing-masing. Ketentuan ini diatur pada pasal 4 Kompilasi Hukum Islam "Perkawinan adalah sah apabila dilakukan menurut hukum Islam". Pada pasal 2 Undang-undang Nomor 1 tahun 1974, menyatakan "Perkawinan adalah sah, apabila dilakukan menurut hukum masingmasing agamanya dan kepercayaannya itu". Ketentuan ini memberi pemahaman bahwa perkawinan beda agama tidak dibenarkan, bahkan dalam Kompilasi Hukum Islam lebih dikongkritkan lagi bahwa agama yang dimaksud adalah agama (hukum) Islam. Pengaturan larangan perkawinan beda agama ini lebih dipertegas lagi pada pasal berikutnya dalam Kompilasi Hukum Islam yang menyebutkan adanya larangan kawin seorang lelaki dengan seorang wanita yang tidak beragama Islam, dan larangan seorang wanita Islam untuk melangsungkan perkawinan dengan seorang pria yang tidak beragama Islam (pasal 40 huruf $\mathrm{c}$ dan pasal 44 Kompilasi Hukum Islam).
Adanya larangan untuk melangsungkan perkawinan beda agama baik yang dipahami secara langsung dari ketentuan yang ada dalam Kompilasi Hukum Islam (pasal 40 huruf c dan pasal 44 Kompilasi Hukum Islam), maupun yang dipahami secara inplisit pada pasal 2 ayat (1) Undang-undang Nomor 1 tahun 1974, merupakan sebuah pembaruan dalam hukum Islam.

\section{e. Tata Cara Perceraian (Talak)}

Dalam rumusan kitab fikih, terkesan suami memiliki kemudahan untuk melakukan perceraian karena talak itu diposisikan sebagai hak suami, kapan saja dan dimana saja suami dapat mentalak isterinya. Berbeda halnya dalam beberapa ketentuan dalam Kompilasi Hukum Islam, dimana perceraian itu dibuat sedemikian rupa sehingga seseorang tidak begitu mudah melakukan perceraian, bahkan tidak dibolehkan melakukan perceraian tanpa alasan yang jelas dan dibenarkan oleh peraturan perundang-undangan. Pengaturan perceraian ini dapat dilihat pada 
Abduh Sulaeman, Pembaruhan Hukum Islam Dalam Kompilasi Hukum Islam Sebagai Upaya...

pasal 115 Kompilasi Hukum Islam

"Perceraian hanya dapat dilakukan

di depan sidang Pengadilan Agama setelah Pengadilan Agama tersebut berusaha dan tidak dapat berhasil mendamaikan kedua belah pihak".

\section{Bidang Hukum Kewarisan}

\section{a. Pergantian Kedudukan (mawali).}

Ahli waris merupakan salah satu unsur dalam sistem kewarisan. Ahli waris adalah orang yang berhak atas harta warisan yang ditinggalkan oleh orang yang meninggal yang terdiri dari orang yang mempunyai hubungan kekerabatan dan hubungan perkawinan dengan pewaris yang meninggal. Penentuan ahli waris yang berhak menerima warisan dari pewaris telah ditetapkan secara jelas pada masing-masing sistem hukum kewarisan yang ada, seperti pada hukum kewarisan Islam, hukum Kewarisan adat, ataupun hukum kewarisan perdata barat.

Dalam sistem hukum kewarisan Islam penentuan siapa yang menjadi ahli waris pewaris, telah ditetapkan secara limitatif dengan membagi kepada tiga golongan, yaitu dzawil furūd (ahli waris tertentu yang telah diberikan bagian tertentu), ashabah, yaitu ahli waris yang tidak ditentukan bagiannya tetapi mengambil sisa harta yang telah dibagi oleh dzawil furūd, dan dzawil Arhām adalah ahli waris yang tidak termasuk dalam kategori dzawil furūd dan ashabah dan mendapatkan warisan ketika tidak ada golongan dzawil furūd dan ashabah. Selain ketentuan menganai siapa yang berhak menerima warisan, juga ditetapkan adanya keadaan yang harus dimiliki oleh ahli waris yang dimaksud pada saat meninggalnya pewaris, yaitu (1) ahli waris itu telah atau masih hidup pada waktu meninggalnya pewaris (2) tidak ada hal-hal yang menghalanginya secara hukum untuk menerima warisan dan (3) tidak terhijab atau tertutup secara penuh oleh ahli waris yang lebih dekat (Amir Syarifuddin, 2004:220).

Dalam kaitannya dengan ketetapan mengenai ahli waris yang berhak menerima kewarisan dengan syarat dan ketentuan 
Abduh Sulaeman, Pembaruhan Hukum Islam Dalam Kompilasi Hukum Islam Sebagai Upaya...

seperti disebutkan di atas, dalam masyarakat muncul sebuah pertanyaan tentang bagaimana kedudukan ahli waris yang lebih duluan meninggal dari pada pewaris, khususnya ahli waris cucu yang lebih dahulu meninggal ayah atau ibunya apakah dapat menggantikan kedudukan bapak atau ibunya yang telah meninggal pada saat meninggalnya pewaris. Jika kita berdasar pada ketentuan mengenai ahli waris dalam sistem hukum kewarisan Islam sebagaiamana disebutkan di atas, maka meskipun telah ditetapkan sebagai ahli waris yang berhak menerima warisan tetapi tetap disyaratkan bahwa ahli waris yang dimaksud harus dalam keadaan masih hidup, maka dapat dipahami bahwa ahli waris yang telah meninggal lebih duluan dari pewaris, dia tidak memiliki hak untuk mendapatkan warisan. Dalam hal ini sistem kewarisan Islam tidak mengenal adanya pergantian kedudukan ahli waris jika ahli waris yang dimaksud lebih dahulu meninggal. Cucu yang memperoleh kewarisan dalam hukum waris Islam, bukan karena menggantikan kedudukan ayah atau ibunya yang telah meninggal tetapi karena kedudukannya sebagai cucu yang digolongan sebagai salah satu ahli waris.

Khusus untuk mengantisipasi ketiadaan pusaka cucu dalam hal ayah atau ibunya yang telah meninggal dunia, di berbagai negara muslim telah diatasi dengan memberikan wasiat wājibah, tetapi tetap bukan dengan istilah pergantian kedudukan, yaitu menganti kedudukan ayah atau ibunya. Negara Mesir, misalnya melalui undang-undang Nomor 71 tahun 1946 memberlakukan wasiat wäjibah terhadap cucu yang ayah atau ibunya telah meninggal dunia lebih dahulu dari pewaris. Negara Suriah melalui Undang-Undang Personal Status Suriah tahun 1953, wasiat wājibah diberlakukan bagi keturunan langsung melalui garis anak laki-laki yang meninggal lebih dahulu dari pewaris (ayahnya), dan tidak berlaku bagi keturunan langsung melalui anak perempuan. Marokko melalui 


\begin{abstract}
undang-undang Personal Status
Marokko tahun 1957

memberlakukan wasiat Wäjibah

seperti di Suriah. Kemudian

Tunisia melalui Undang-Undang

Personal Status Tunisia tahun 1956

memberlakukan wasiat wājibah

bagi keturunan langsung malalui

garis laki-laki atau perempuan

yang meninggal dunia lebih dahulu

dari pewaris (Abdullah Sidik,
\end{abstract}

2013:87-88).

Berbeda dengan hukum kewarisan dalam berbagai kitab fiqhi dan pembaruan hukum waris yang dilakukan oleh berbagai negara, Kompilasi Hukum Islam telah membenarkan adanya pergantian kedudukan dalam sistem kewarisan Islam. Ketentuan ini dapat dilihat pada Pasal 185 KHI yang menetapkan bahwa (1) Ahli waris yang meninggal lebih dulu dari pada pewaris, maka kedudukannya dapat digantikan oleh anaknya, kecuali mereka yang tersebut dalam Pasal 173, dan ayat (2) Bagian ahli waris pengganti tidak boleh melebihi dari bagian ahli waris yang sederajat dengan yang diganti.

\section{b. Pelembagaan}

Wasiat

Wäjibah untuk Ahli Waris

Anak Angkat

Pengangkatan anak sudah merupakan sesuatu yang lazim dijumpai dalam masyarakat. Dalam Kamus Besar Bahasa Indonesia disebutkan bahwa pengangkatan anak adalah pengangkatan anak orang lain yang diambil (dipelihara) serta disahkan secara hukum sebagai anak sendiri (Departemen

Pendidikan

Nasional, 2008:56). Pengangkatan anak juga dikenal dengan istilah adopsi yang berasal dari bahasa Inggris yaitu "adoption" atau dari bahasa Belanda "adoptie", yang berarti pengambilan atau pengangkatan anak orang lain secara sah menjadi anak sendiri (Sudarsono, 2007:18). Dalam berbagai literatur Islam, pengangkatan anak disebut dengan istilah "tabanny" yang berarti pengambilan anak yang dilakukan oleh seseorang terhadap anak yang jelas nasabnya, kemudian anak itu dinasabkan kepada dirinya (Wahbah az Zuhaili, 2006:271). 
Agama Islam pada dasarnya tidak melarang praktek pengangkatan anak, sejauh tidak mempengaruhi dan tidak merubah hubungan nasab atau keturunan antara anak dengan orang tua kandungnya.

Praktek pengangkatan anak akan dilarang ketika hal ini berakibat keluarnya anak angkat dari hubungan nasab atau keturunan antara anak dengan orang tua kandungnya sendiri dan masuk dalam hubungan nasab dengan orang tua angkatnya dan tidak pula menyebabkan hak waris antara keduanya. Dengan demikian, dalam konsepsi hukum Islam, pengangkatan anak tidak membawa akibat hukum dalam hal hubungan darah, hubungan walimewali dan hubungan waris mewaris dengan orang tua angkat. Ia tetap menjadi ahli waris dari orang tua kandungnya dan anak tersebut tetap memakai nama dari ayah kandungnya (M. Budiarto, 1991). Menurut Hukum Islam anak angkat tidak dapat diakui untuk bisa dijadikan dasar dan sebab mewarisi karena prinsip pokok dalam kewarisan Islam adalah hubungan darah atau Arhām (Hilman Hadikusuma, 1990:78). Dengan kata lain, peristiwa pegangkatan anak menurut hukum kewarisan Islam, tidak membawa pengaruh hukum terhadap status anak angkat, yakni bila bukan merupakan anak sendiri, maka anak angkat tidak dapat mewarisi dari orang yang telah mengangkatnya.

Dalam hal kewarisan anak angkat, Kompilasi Hukum Islam memberikan rumusan berbeda dengan kitab-kitab fikih yang ditulis sebelumnya. Kompilasi Hukum Islam menentukan bahwa meskipun anak angkat dan orang tua angkat bukan sebagai ahli waris yang berkedudukan sama dengan anak kandung sebagaimana telah dipertegas dalam berbagai kitab fikih, tetapi anak angkat dan orang tua angkat akan memeperoleh warisan sebagaimana dipraketkkan oleh masyarakat adat Indonesia, sekalipun warisan tersebut diperoleh melalui wasiat Wãjibah, yaitu tindakan yang dilakukan oleh penguasa atau hakim sebagai 
aparat negara untuk memaksa atau memberi putusan wajib wasiat bagi orang yang telah meninggal, yang diberikan kepada orang tertentu dalam keadaan tertentu. Dengan kata lain wasiat wäjibah adalah wasiat yang pelaksanaannya tidak dipengaruhi atau tidak bergantung kepada kehendak orang yang meninggal dunia. Wasiat ini tetap dilaksanakan baik diucapkan atau dikehendaki, maupun tidak oleh orang yang meninggal dunia.

$$
\text { Jadi pelaksanaannya }
$$

didasarkan kepada alasan-alasan hukum yang membenarkan bahwa wasiat tersebut harus dilaksanakan (Suparman Usman, 1997:163). Pengaturan tentang pelembagaan wasiat wäjibah yang diperuntukkan kepada anak angkat dapat dilihat pada pasal 209 Kompilasi Hukum Islam yang menyatakan (1) Harta peninggalan anak angkat dibagi berdasarkan Pasal 176 sampai dengan 193 tersebut di atas, sedangkan terhadap orang tua angkat yang tidak menerima wasiat diberi wasiat wäjibah sebanyakbanyaknya $1 / 3$ dari harta wasiat anak angkatnya. (2) Terhadap anak angkat yang tidak menerima wasiat diberi wasiat wājibah sebanyakbanyaknya $1 / 3$ dari harta warisan orang tua angkatnya. Pasal 209 Kompilasi Hukum Islam ini menetapkan bahwa anak angkat dan ayah angkat masing-masing mendapat harta warisan berupa wasiat wājibah. Jika si anak angkat meninggal dunia, maka ayah angkat secara otomatis berhak mendapatkan wasiat wājibah dari harta warisan si anak angkat tersebut. Sebaliknya, jika ayah angkat meninggal dunia dan meninggalkan warisan, si anak angkat juga berhak mendapat wasiat wäjibah dari harta warisan tersebut.

Dari uraian di atas dapat disimpulkan bahwa pelembagaan wasiat wäjibah untuk kewarisan anak angkat merupakan salah satu aspek yang mengalami pembaruan dalam penerapan hukum Islam yang termuat dalam Kompilasi Hukum Islam.

\section{c. Sistem Kewarisan Kolektif}

Kewarisan pada hakikatnya adalah sistem peralihan harta 
Abduh Sulaeman, Pembaruhan Hukum Islam Dalam Kompilasi Hukum Islam Sebagai Upaya...

kekayaan seseorang yang telah meninggal kepada orang yang telah ditetapkan sebagai ahli waris berdasarkan ketentuan hukum yang berlaku. Dengan demikian terlaksananya sistem kewarisan dalam masyarakat ditandai dengan adanya peralihan harta orang yang telah meninggal kepada individu tertentu yang dipandang sebagai ahli waris dengan jumlah bagian yang telah ditentukan menurut hukum yang berlaku.

Dalam Hukum Islam, sistem kewarisan menduduki tempat yang amat penting, dan ayat Al-Quran sebagai sumber utama hukum Islam telah mengatur dangan jelas dan terperinci. Salah satu bentuk pengaturan kewarisan dalam Islam dikenal adanya azas Individual, yaitu harta warisan dibagi untuk dimiliki secara perseorangan. Masing-masing ahli waris menerima bagiannya secara tersendiri tanpa terikat dengan ahli waris lainnya (Suparman Usman, 1997:25). Azas individual ini dapat dipahami dari ayat-ayat kewarisan yang telah menentukan ahli waris yang berhak menerima warisan dari seorang yang telah meninggal dengan jumlah bagian yang telah ditentukan. Di antara ayat tersebut adalah surah an Nisa ayat $7,11,12$ dan 176 .

Dari beberapa ayat yang disebutkan di atas, masih terlihat adanya ketetapan ahli waris mendapat bagian secara bersamasama seperti anak laki-laki bersama dengan anak peremapuan (surah an Nisa ayat 11), saudara laki-laki dan saudara perempuan dalam ayat 176 , dua orang anak perempuan mendapat dua pertiga dalam ayat 11 , dua orang saudara perempuan mendapat dua pertiga dalam ayat 176, dan saudarasauadara yang berserikat dalam mendapatklan sepertiga harta bila pewaris adalah seorang yang tidak memiliki ahli waris, namun menurut Amir Syarifuddin "Penetapan bagian ahli waris secara bersama dalam bentuk kolektif ini hanya untuk sementara yaitu sebelum terjadi pembagian yang bersifat individual di antara mereka" (Suparman Usman, 1997:26). 
Dalam Kompilasi Hukum Islam ditemukan adanya kemungkinan pewarisan dilakukan dengan sistem kolektif, sekalipun dalam hukum kewarisan Islam yang telah ada di berbagai kitab fikih tidak mengenal adanya ketentuan mengenai sistem pewarisan kolektif, tetapi hanya semata-mata mengenal sistem pewarisan individual sebagaimana telah diuraikan sebelumnya. Pewarisan dengan sistem kollektif dimana harta peninggalan diteruskan dan dialihkan pemilikannya dari pewaris kepada waris sebagai kesatuan yang tidak terbagi-bagi penguasaan dan pemilikannya, melainkan setiap waris berhak untuk mengusahakan, menggunakan atau mendapat hasil dari harta peninggalan itu. Bagaimana cara pemakaian untuk kepentingan dan kebutuhan masing-masing waris diatur bersama atas dasar musyawarah dan mufakat oleh semua anggota kerabat yang berhak atas harta peninggalan di bawah bimbingan kerabat (Hilman Hadikusuma, 1990:26).
Sistem pewarisan kolektif dalam Kompilasi Hukum Islam dapat dilihat keberadaannya pada Pasal 189 (1) Kompilasi Hukum Islam yang meyatakan: (1) Bila harta warisan yang akan dibagi berupa lahan pertanian yang luasnya kurang dari dua hektar supaya dipertahankan sebagainama semula, dan dimanfaatkan untuk kepentingan bersama para ahli waris yang bersangkutan, (2) Bila ketentuan dalam ayat 1) pasal ini tidak memungkinkan karena di antara ahhli waris yang bersangkutan ada yang memerlukan uang, maka lahan tersebut dapat dimiliki oleh seorang atau lebih ahli waris yang berhak sesuai dengan bagiannya masing-masing, dengan cara memiliki lahan menggantikan atau memberikan kompensasi sebesar atau senilai bagian ahli waris yang membutuhkannya.

Pasal 189 KHI di atas menunjukkan bahwa dalam rumusan Kompilasi Hukum Islam telah terjadi pembaruan di bidang hukum kewarisan Islam, khususnya dalam sistem pewarisan 
Abduh Sulaeman, Pembaruhan Hukum Islam Dalam Kompilasi Hukum Islam Sebagai Upaya...

harta warisan yang hanya mengenal sistem pewarisan individual sebagaimana tertuang dalam berbagai kitab fikih yang membahas masalah kewarisan (fiqh Mawāris ), menjadi disamping sistem pewarisan individual juga sistem pewarisan kolektif, meskipun penggunaannya terbatas, yaitu hanya berlaku apabila harta warisan yang dibagi menyulitkan pelaksanaannya, dan cenderung mengakibatkan kerugian bagi ahli waris, yaitu ketika harta warisan yang akan dibagi berupa lahan pertanian yang luasnya kurang dari 2 hektar.

\section{Keberadaan Pembaruan Hukum Islam dalam Kompilasi Hukum Islam}

Dari beberapa aspek materi hukum Islam yang telah mengalami pembaruan sebagaimana diseutkan di atas, dapat dipahami bahwa: keberadaan pembaruan hukum Islam melalui Kompilasi Hukum Islam masih parsial dan tidak bersifat menyeluruh untuk beberapa

ketentuan hukum Islam, sehingga dalam hal beberapa peristiwa hukum telah menjadi adat ('urf) masyarakat dan telah dipandang memiliki maslahat tidak menjadi obyek atau sasaran pembaruan. Misalnya porsi pembagian ahli waris dua berbanding satu untuk warisan kelompok laki-laki dan perempuan masih tetap dipertahankan pada hal adat atau 'urf masyarakat tertentu telah menetapkan adanya kesetaraan antara laki-laki dan perempuan dalam pembagian warisan, sementara untuk ketentuan hukum Islam dalam hal kewarisan anak angkat dalam bentuk wasiat Wäjibah, kewarisan cucu yang lebih dahulu meninggal bapak atau ibunya, keabsahan seorang anak, sudah dapat diperbarui dengan mengapresiasi budaya lokal masyarakat. Pembatasan obyek atau sasaran pembaruan hukum Islam pada aspek-aspek hukum tertentu dan mengabaikan ketentuan hukum Islam yang lain menunjukkan bahwa para perumus Kompilasi Hukum Islam menganut paham adanya limitasi ruang 
lingkup ijtihad yang membatasi kebolehan ijithad hanya pada ketentuan hukum yang didasarkan kepada dalil dzanny, dan meniadakan untuk melakukan ijtihad atau pembaruan terhadap ketentuan hukum yang didasarkan kepada dalil qath'i. Porsi bagian ahli waris dua berbanding satu untuk bagian laki-laki dan perempuan adalah ketentuan bagian ahli waris yang didasarkan kepada dalil qath' $i$ yaitu surah anNisa ayat 11, tidak dilakukan pembaruan sekalipun telah menjadi budaya lokal bagi masyarakat tertentu dan ratio legienya mengandung sebuah kemaslahatan. Para ushuliyūun hampir sependapat menetapkan adanya pembatasan obyek ijtihad, disamping pembatasan dari aspek hukum-hukum syara yang sifatnya furu' dan sifatnya $u s h u l$, juga dari aspek dukungan dalil syar'i antara dalil qath'i dan dalil dzany. Dalam hal ini para ushuliyūn membatasi obyek ijtihad hanya pada masalahmasalah furu' dan masalah yang didasarkan pada dalil dzany, sedang untuk masalah ushul dan masalah yang didasakan kepada dalil yang sifatnya qath'i tidak dibenarkan untuk melakukan ijtihad. Al Gazali misalnya menegaskan bahwa ijtihad hanya boleh dilakukan terhadap hukum syara' yang tidak ada dalil qath ' $i$ nya (al Gazaly, Abu Hamid Muhammad bin Muhammad, Tt: 482).

Senada dengan itu as Syaukani menegaskan, bahwa yang menjadi obyek ijtihad adalah segenap hukum syara' yang bukan didasarkan atas dalil yang qath'I (Muhammad bin Ali bin Muhammad Al Syaukany, Tt:250). Demikian pula dengan al Amidi yang menetapkan bahwa hal-hal yang boleh diijtihadi adalah hukum-hukum syara' yang petunjuk hukumnya bersifat $d z a n n i$ (Muhammad bin 'Ali al-Amidī, 1986:171). Ibnu Qayyim al Jauzai menyatakan keharaman memberi fatwa dan memutuskan hukum dalam persoalan-persoalan agama jika bertentangan dengan nash serta tidak dibolehkan berijtihad dan bertaqlid jika sudah ada nash yang jelas. Jadi, bila sudah ada 
nash yang jelas maka tidak ada ruang bagi ijtihad (Ibnu Qayyim alJauziyah, Tt:199). Pembatasan ruang lingkup ijtihad sebagaimana disebutkan di atas sejalan dengan kaidah ushuliyyūn yang menyatakan "Tidak ada ijtihad ketika (hukum) dinyatakan dalam nash", atau dengan redaksi lain "tidak boleh melakukan ijtihad saat ada nash". Artinya ketika nash sudah menyatakan secara tegas ketentuan hukumnya, maka tidak ada ruang bagi ijtihad untuk mencari alternatif hukum lain, selain yang dinyatakan oleh nash.

Terlepas dari pandangan ulama tentang pembatasan ruang lingkup ijtihad sebagaimana disebutkan diatas, dalam perkembangan ijtihad telah ditemukan adanya pendapat untuk tidak melakukan pembatasan terhadap lingkup ijtihad yaitu tidak hanya terbatas pada dalil dzani tetapi juga terhadap dalil qath'i. Diantara teoritisi hukum Islam yang berpendapat seperti itu adalah Khaled M. Abou el-Fadlal. Beliau menegaskan bahwa Al-Quran dan Sunnah adalah merupakan "karya yang terus berubah". Keduanya merupakan teks-teks hukum yang terbuka (the open texts) yang membiarkan diri mereka terbuka bagi berbagai strategi interpretasi. Jika teks tidak lagi mampu berbicara atau dibungkam suaranya, tidak ada alasan menggeluti teks, dan bagaimanapun teks sudah membeku dan tertutup dalam kondisi terakhir ketika ia ditafsirkan. Penutupan teks ini terjadi ketika pembaca bersikeras bahwa teks mengandung makna yang telah ditentukan, stabil, tetap dan tidak berubah (Khaled M. Abou el-Fadl, 2004:212-213). Ilyas Supena dan M. Fauzi memiliki pandangan yang sama dengan Khaled M. Abou el-Fadlal. Keduanya menyatakan kebutuhan terhadap ijtihad bukan hanya berlaku bagi nash-nash yang dzanny, melainkan juga bagi nash qath 'iy al dalālah. Meskipun nashnya qathi'yah al dalālah, tetapi kandungan hukumnya terkait dengan urusan yang menerima perubahan, maka tidak ada salahnya (secara temporal- 
kasuistis) hukum yang disebutkan nash tersebut dikesampingkan, apabila hikmah dan maslahatnya menghendaki lain (Ilyas Supena dan M. Fauzi, 2002:276).

Dari uraian di atas dapat disimpulkan bahwa para perumus Kompilasi Hukum Islam dalam melakukan pembaruan hukum Islam, masih berpegang kepada pandangan mayoritas ulama ushuliyyūn yang memberi batasan tentang ruang lingkup ijtihad, yaitu terbatas pada ketentuan yang didasarkan pada dalil-dalil dzany dan tidak terhadap ketentuan hukum yang didasarkan kepada qath'i.

Bahwa substansi hukum Islam yang diperbarui dalam Kompilasi Hukum Islam, hanyalah hukum Islam yang dikategorikan sebagai hukum Islam yang sifatnya qadha'i bukan hukum Islam yang bersifat diyāni. Hukum yang bersifat Qadhāi, adalah hukum Islam yang membutuhkan kekuasaan negara untuk melaksanakannya. Tanpa aturanaturan pelaksanaan dalam sistem hukum nasional terhadap norma- norma hukum Islam ini, ia tidak akan mendapat penerimaan yang layak dan efektif dalam masyarakat, sedangkan hukum bersifat Diyāni, adalah hukum yang tidak membutuhkan kekuasaan negara, pelaksanaannya diserahkan sepenuhnya kepada kesadaran masyarakat secara individu.

Pembatasan rung lingkup pembaruan hukum Islam dalam proses perumusan Kompilasi Hukum Islam sebagaimana disebutkan di atas dapat juga dipahami dari konsideran Keputusan Bersama Ketua MA dan Menteri Agama tanggal 21 Maret 1985 No.07/KMA/1985 dan No. 25 Tahun 1985 tentang Penunjukan Pelaksanaan Proyek Pembangunan Hukum Islam melalui yurisprudensi disebutkan adanya dua pertimbangan, yaitu:

a. Bahwa sesuai dengan fungsi pengaturan MA RI terhadap jalannya peradilan disemua lingkungan peradilan di Indonesia, khususnya di lingkungan Peradilan Agama, perlu mengadakan Kompilasi 
Hukum Islam yang selama ini dijadikan hukum positif di Pengadilan Agama;

b. Bahwa guna mencapai maksud tersebut, demi meningkatkan kelancaran pelaksanaan tugas, sinkronisasi dan tertib administrasi dalam proyek Pembangunan Hukum Islam melalui yurisprudensi, dipandang perlu membentuk suatu tim proyek yang susunannya terdiri dari para Pejabat MA dan Departemen Agama RI.

Dari konsideran yang disebutkan di atas memberi pemahaman bahwa latar belakang diadakannya Kompilasi Hukum Islam adalah adanya keperluan untuk memenuhi ketersediaan hukum positif yang dapat menjadi hukum terapan pada lingkungan badan Peradilan Agama yang diberi kewenangan untuk menangani perkara-perkara tertentu bagi umat Islam dengan berdasarkan kepada hukum Islam.

Dari pembahasan di atas dapat disimpulkan bahwa pembaruan hukum Islam melalui kompilasi hukum Islam sebagai upaya positivisasi hukum, hanya terbatas pada aspek hukum Islam yang bersifat qadhäi dan tidak masuk kepada hukum Islam yang bersifat diyāni. Pembaruan hukum Islam dalam Kompilasi Hukum Islam terbatas pada aspek yang membutuhkan kekuasaan negara untuk pelaksanaannya, sementara aspek yang berkaitan dengan hukum Islam yang tidak membutuhkan kekuasaan negara untuk pelaksanaannya sepenuhnya diserahkan kepada kesadaran masyarakat secara individu, dan tidak menjadi obyek pembaruan hukum. Keadaan ini juga menunjukkan bahwa adanya pemilahan obyek pembaruan hukum Islam berdaarkan sistem prioritas penggunaannya dalam masyarakat yang menjadi sasaran pengaturannya.

\section{PENUTUP}

\section{Simpulan}

a. Keberadaan pembaruan hukum Islam dalam Kompilasi Hukum Islam sebagai upaya positivisasi 


$$
\begin{aligned}
& \text { hukum (1) terbatas pada } \\
& \text { ketetapan yang didasarkan } \\
& \text { pada dalil zanny sehingga } \\
& \text { terhadap peristiwa hukum } \\
& \text { yang didasarkan pada dalil- } \\
& \text { dalil qaț'i yang bersumber } \\
& \text { dari Al-Quran dan Sunnah } \\
& \text { tidak tersentuh dengan } \\
& \text { proses pembaruan, } \\
& \text { terbatas pada hukum Islam } \\
& \text { yang bersifat qadha'i yaitu } \\
& \text { hukum Islam membutuhkan } \\
& \text { kekuasaan negara untuk } \\
& \text { pelaksanaannya sementara } \\
& \text { aspek yang berkaitan dengan } \\
& \text { hukum Islam yang tidak } \\
& \text { membutuhkan kekuasaan } \\
& \text { negara tidak menjadi obyek } \\
& \text { pembaruan hukum, dan (3) } \\
& \text { dukungan dalil syar'i } \\
& \text { terhadap pembaruan hukum } \\
& \text { dimungkinkan berupa dalil- } \\
& \text { dalil yang bersifat umum. }
\end{aligned}
$$

b. Para perumus Kompilasi Hukum Islam dalam melakukan pembaruan hukum Islam, masih berpegang kepada pandangan mayoritas ulama ushuliyyūn yang memberi batasan tentang ruang lingkup ijtihad, yaitu terbatas pada ketentuan yang didasarkan pada dalil-dalil dzany dan tidak terhadap ketentuan hukum yang didasarkan kepada qath'i.

\section{Saran}

a. Untuk terlaksananya usaha pembaruan hukum Islam dalam upaya positivisasi hukum maka diperlukan adanya perubahan pradigma masyarakat yang memandang hukum Islam sebagai hukum Tuhan, mengabaikan persepsi dan perilaku masyarakat dalam pembentukan hukumnya, ke pradigma masyarakat yang memandang bahwa meskipun hukum Islam adalah hukum Tuhan, namun pembentukannya

memungkinkan dilakukan dengan pendekatan induktif yang berangkat dari realitas hidup masyarakat.

b. Perubahan pradigma masyarakat ini harus bermula pada usaha-usaha yang dilakukan oleh lembaga- 
lembaga pendidikan Islam di pondok-pondok pesantren dan lembaga pendidikan tinggi Islam, dengan memperkenalkan sumbersumber atau dalil - dalil hukum Islam tidak hanya sebatas dengan Al Quran, Sunnah Rasul, Ijma dan Qiyas, tetapi juga dengan sumber-sumber lain seperti istihsan, maslahat mursalah dan 'urf masyarakat setempat.

\section{DAFTAR PUSTAKA}

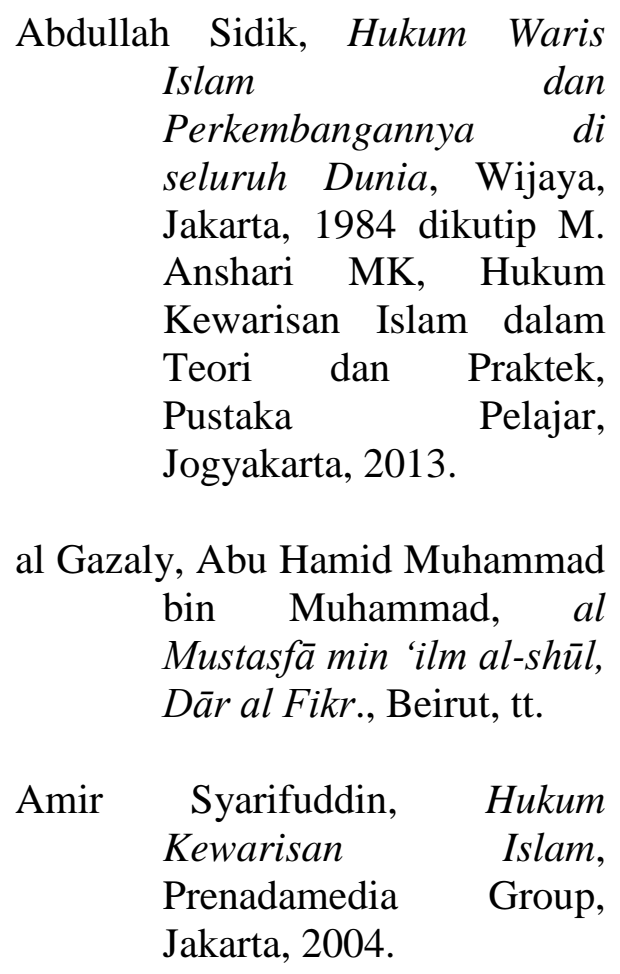

Busthanul Arifin, Pelembagaan Hukum Islam di Indonesia, Akar Sejarah, Hambatan dan Prospeknya, Gema Insani, Jakarta, 1996.

Departemen Agama RI, al-Quran dan Terjemahnya, Pustaka Amani, Jakarta, 2005.

Departemen Pendidikan Nasional, Kamus Besar Bahasa Indonesia, Gramedia Pustaka Utama, Jakarta, 2008.

Hadikusuma, Hukum Waris Adat, Citra Aditya Bakti, Bandung. 1990.

Ibnu Qayyim al-Jauziyah, I'lam alMuwaqqi'inn 'an Rabb al'àlamìn, Beirut: Dār alJil, tt.

Ilyas Supena dan M. Fauzi, Dekonstruksi dan Rekonstruksi Hukum Islam, Gama Media, Jogyakarta, 2002.

Khaled M. Abou el-Fadl, Atas Nama Tuhan, alih bahasa Cecep Lukman Yasin, cet. ke-1 Jakarta: PT. Serambi Ilmu Semesta, 2004.

Khoiruddin Nasution, Status Wanita di Asia Tenggara (Studi terhadap Perundang-undangan Perkawinan Muslim Kontemporer di Indonesia dan Malaysia), INIS, Jakarta, 2002. 
Abduh Sulaeman, Pembaruhan Hukum Islam Dalam Kompilasi Hukum Islam Sebagai Upaya...

M. Budiarto, Pengangkatan Anak Ditinjau Dari Segi hukum, AKAPRESS, 1991.

Muhammad bin 'Ali al-Amidī, alIhkām fi Ușūl al-Ahkām Beirut: Dār al-Kitab alArabī, 1986.

Muhammad bin Ali bin Muhammad Al Syaukany, Irsyadul al Fuhul, Dārl al Fikr, Beirut, tt.

Muhammad Jawad Mughniyah, al Fiqh 'alā al Madzāhib alKhamsah, diterjemahkan oleh Masykur A.B. dkk, dengan judul "Fiqih Lima Madzhab", Lentera, Jakarta, 2007.

Sudarsono, Kamus Hukum, Rineka Cipta, Jakarta, 2007.

Suparman Usman, Fikih Mawāris Hukum Kewarisan Islam, Gaya Media Pratama, Jakarta, 1997.
Wahbah az Zuhaili, al Fiqh Islam wa adillatuhu, Juz IX, Dārl al Fikr al Ma'ashi, Beirut, 2006. 